\title{
PENGEMBANGAN METODE PEMBELAJARAN DUKASIMERA BERBASIS KEARIFAN LOKAL PADA SMAN 1 BANJAR, BULELENG, BALI
}

\author{
Gede Putra Adnyana \\ SMAN 1 Banjar, Buleleng, Bali \\ Email: putradnyana@gmail.com
}

\begin{abstract}
Abstrak
Penelitian ini bertujuan mengembangkan dan mengetahui pengaruh metode pembelajaran dukasimera berbasis kearifan lokal terhadap hasil belajar peserta didik SMAN 1 Banjar, Buleleng, Bali tahun pelajaran 2017/2018. Penelitian ini menggunakan pendekatan penelitian dan pengembangan (R\&D) dengan model ADDIE. Data dikumpulkan dengan metode observasi, wawancara, angket, dan tes. Data dianalisis secara deskriptif untuk menentukan kevalidan dan keefektifan metode pembelajaran. Hasil penelitian menunjukkan bahwa metode pembelajaran dukasimera dapat dikembangkan untuk meningkatkan keterlibatan peserta didik dalam pembelajaran. Rerata hasil belajar peserta didik yang mengikuti pembelajaran dengan metode dukasimera sebesar 77,08 lebih tinggi dari pembelajaran langsung sebesar 68,49. Dengan demikian, hasil belajar peserta didik dengan metode dukasimera lebih baik dibandingkan dengan pembelajaran langsung.
\end{abstract}

Kata kunci: metode dukasimera, kearifan lokal

\begin{abstract}
This study aims to develop and find out the influence of local wisdom-based dukasimera learning methods on the learning outcomes of students of SMAN 1 Banjar, Buleleng, Bali in the 2017/2018 academic year. This study uses a research and development $(R \& D)$ approach with the ADDIE model. Data collected by the method of observation, interviews, questionnaires, and tests. Data were analyzed descriptively to determine the validity and effectiveness of learning methods. The results of the study showed that the method of supporting learning can be developed to increase the involvement of students in learning. The mean learning outcomes of students who took part in learning by the gait method were 77.08 higher than direct learning at 68.49. Thus, the learning outcomes of students with the support method are better than direct learning.
\end{abstract}

Keywords: dukasimera method, local wisdom

\section{PENDAHULUAN}

Kajian dalam mata pelajaran prakarya dan kewirausahaan ada yang bersifat abstrak berupa ide atau gagasan dan bersifat konkret berupa produk. Oleh karena itu, pembelajaran diarahkan dalam kerangka mengembangkan kecakapan hidup berbasis seni dan teknologi (Kementerian Pendidikan dan Kebudayaan Republik Indonesia, 2017). Hal ini sesuai dengan pendapat Sarbani et al., (2013) bahwa 
penguasaan teknologi dan informasi sangat penting bagi peserta didik untuk mempersiapkan diri memasuki dunia kerja.

Pembelajaran prakarya dan kewirausahaan hendaknya akomodatif dengan perkembangan teknologi dan informasi. Hal ini sangat bermanfaat untuk mengeksplorasi ide, proses, dan produk yang berbasis lingkungan, sosial, dan budaya. Oleh karena itu, dalam pembelajaran prakarya dan kewirausahaan, terkandung unsur pengetahuan, keterampilan, sikap, seni, teknologi, lingkungan, ergonomi, ekonomi, dan budaya. Kondisi ini memberikan ruang dan waktu lebih luas bagi pembelajaran yang kreatif, inovatif, dan menyenangkan. Mulyaningsih dkk. (2016) menyebutkan bahwa metode dan strategi pembelajaran kreatif dan inovatif dapat mewujudkan pembelajaran yang aktif dan menyenangkan. Akibatnya, tujuan pembelajaran dapat tercapai secara sangkil dan mangkus.

Fakta di lapangan menunjukkan, mata pelajaran prakarya dan kewirausahaan dipandang sebelah mata oleh sebagian guru dan peserta didik. Mereka cenderung menyamakan dengan mata pelajaran keterampilan sehingga orientasinya hanya sebatas produk prakarya. Akibatnya, pembelajaran aspek prakarya lebih mendominasi dan nyaris meniadakan aspek kewirausahaan. Padahal, aspek kewirausahaan sangat penting dalam kerangka meningkatkan nilai tambah produk prakarya.

Kajian mata pelajaran prakarya dan kewirausahaan di SMA meliputi empat aspek, yakni kerajinan, rekayasa, budidaya dan pengolahan (Kementerian Pendidikan dan Kebudayaan Republik Indonesia, 2017). Keempat aspek tersebut sangat potensial diintegrasikan dengan kearifan lokal dalam pembelajaran. Namun, fakta menunjukkan pembelajaran prakarya dan kewirausahaan cenderung mengabaikan kearifan lokal. Akibatnya, pembelajaran menjadi tidak kontekstual dan tidak mengaitkan dengan adat istiadat, seni, dan budaya setempat. Padahal, kearifan lokal dapat dijadikan sebagai sumber inspirasi dalam mengembangkan ide dan produk menghadapi persaingan global. Hal ini sesuai dengan pendapat Brata (2016) bahwa kearifan lokal sangat penting direvitalisasi untuk memperkuat fondasi jati diri bangsa di era globalisasi.

Berkaitan dengan hal tersebut, pembelajaran prakarya dan kewirausahaan di SMAN 1 Banjar, Buleleng, Bali dapat dilaksanakan dengan mengintegrasikan kearifan lokal Bali yang dijiwai Agama Hindu. Astra \& Semadi (2004) menyebutkan beberapa kearifan lokal Bali diantaranya 1) konsep tri hita karana, 2) tat twam asi, 3) desa kala patra, dan 4) rwa bhineda. Kearifan lokal tersebut dapat diintegrasikan dalam pembelajaran prakarya dan kewirausahaan. Melalui pembelajaran berbasis kearifan lokal, pembelajaran menjadi lebih aktual, faktual, dan kontekstual. Kondisi ini diyakini dapat meningkatkan kualitas proses dan hasil belajar peserta didik.

Pembelajaran berkualitas adalah pembelajaran yang mengembangkan sikap, pengetahuan, dan keterampilan di satu pihak dan memperkuat karakter, kreativitas, dan inovasi di pihak lain. Hasil belajar inilah yang mampu melahirkan peserta didik cerdas dan berkarakter. Oleh karena itu, pembelajaran prakarya dan kewirausahaan yang berkualitas hendaknya dilakukan dengan menerapkan model dan metode pembelajaran yang sesuai dengan karakteristik mata pelajaran dan peserta didik. Kemdikbud (2017) menyebutkan bahwa pembelajaran berkualitas diarahkan untuk membentuk peserta didik beriman dan bertakwa, memiliki integritas moral, keunggulan akademis dan sehat.

Pendekatan pembelajaran yang direkomendasikan dalam kurikulum 2013 adalah pendekatan saintifik. Di mana, peserta didik dilibatkan dalam kegiatan mengamati, menanya, mengumpulkan 
informasi, mengasosiasi atau menalar, dan mengomunikasikan. Muhammad dan Nurdyansyah (2015) menyebutkan bahwa pendekatan saintifik pada prinsipnya menerapkan kaidah ilmiah atau metode ilmiah. Oleh karena itu, pendekatan saintifik perlu dikemas melalui penerapan metode kreatif dan inovatif. Penerapan metode tersebut bertujuan mengharmonisasikan olah pikir, olah rasa, olah hati, dan olah raga. Harmonisasi inilah yang dapat membentuk karakter kuat pada diri peserta didik. Pendidikan karakter diperlukan sebagai tuntunan kepada peserta didik agar menjadi manusia berkarakter dalam dimensi hati, pikir, raga, rasa dan karsa (Iswan \& Herwina, 2018; Saggaf, 2016; Sukmawati, 2017).

Dalam pembelajaran prakarya dan kewirausahaan, ide-ide adalah cikal bakal lahirnya produk. Pembelajaran dimulai dari eksplorasi ide atau gagasan melalui kegiatan pengamatan dan berbagi sehingga dapat direalisasikan menjadi produk. Upaya penggalian ide dan proses pembuatan produk perlu dikomunikasikan dalam bentuk presentasi sebagai uji ide dan produk. Selanjutnya, diseminasi atau memperkenalkan produk kepada publik dalam bentuk pameran sebagai upaya membangun rasa bangga dan percaya diri di kalangan peserta didik. Berkaitan dengan hal tersebut, penerapan metode yang berorientasi Produk, Presentasi, dan Pameran (Dukasimera) dipandang relevan, sangkil, dan mangkus untuk mencapai tujuan pembelajaran prakarya dan kewirausahaan.

Penerapan metode pembelajaran berorientasi produk mengarahkan peserta didik aktif belajar, berpartisipasi, dan berinteraksi dengan peserta didik, guru, dan masyarakat sekitarnya. Kondisi ini dapat mengembangkan kemampuan berpikir dan keterampilan peserta didik (Dewy dkk., 2016). Melalui metode presentasi peserta didik tidak hanya terlibat aktif dalam pembelajaran, tetapi juga menumbuhkembangkan kemampuan berpikir kritis, analitis, dan rasa ingin tahu (Widodo, 2007). Selanjutnya, melalui metode pameran diyakini dapat meningkatkan rasa bangga, menumbuhkan rasa percaya diri, memotivasi lahirnya kreativitas dan inovasi baru.

Berkaitan dengan hal tersebut, dalam penelitian ini dilakukan pengembangan dan penerapan metode pembelajaran dukasimera pada mata pelajaran prakarya dan kewirausahaan. Pembelajaran dengan metode dukasimera berbasis kearifan lokal adalah pembelajaran berorientasi Produk, Presentasi, dan Pameran berbasis kearifan lokal. Penelitian ini dilaksanakan di SMAN 1 Banjar, Buleleng, Bali dengan tujuan mengembangkan dan mengetahui pengaruh metode pembelajaran dukasimera berbasis kearifan lokal pada mata pelajaran prakarya dan kewirausahaan terhadap hasil belajar peserta didik.

\section{METODE PENELITIAN}

Pendekatan penelitian dan pengembangan atau research and development (R\&D) digunakan dalam penelitian ini. Penerapan pendekatan tersebut untuk menghasilkan produk dan menguji keefektifan produk (Creswell \& Poth, 2018). Produk yang diuji adalah metode pembelajaran dukasimera (produk, presentasi, dan pameran) berbasis kearifan lokal.

Model ADDIE, yakni analysis, design, development, implementation and evaluations digunakan dalam penelitian dan pengembangan ini (Almomen dkk., 2016; Branch, 2009; Davis, 2013; Lohr, 1998; Shibley dkk., 2011). Model ADDIE digunakan untuk pengembangan berbagai produk, seperti model, strategi pembelajaran, metode pembelajaran, media dan bahan ajar. Model ADDIE dapat dijadikan pedoman dalam menyusun perangkat dan infrastruktur pengelolaan pelatihan dan pembelajaran (Almomen dkk., 2016; Davis, 2013). 
Pada tahap analisis, dilakukan analisis kompetensi peserta didik, karakteristik pembelajaran, dan materi pelajaran. Selanjutnya, dilakukan perumusan disain produk berupa rencana pelaksanaan pembelajaran (RPP) dan lembar kegiatan peserta didik (LKPD) dengan metode dukasimera berbasis kearifan lokal. Kegiatan pada tahap pengembangan adalah mengembangkan dan memvalidasi RPP dan LKPD. Untuk mengetahui keefektifan metode pembelajaran dan masukan dari guru dan peserta didik, maka dilakukan implementasi produk pada peserta didik SMAN 1 Banjar, Buleleng, Bali kelas X-MIPA-2 dan X-MIPA-3 tahun pelajaran 2017/2018 yang berjumlah 68 orang. Tahap evaluasi dilakukan untuk memberikan nilai terhadap pelaksanaan metode pembelajaran dukasimera berbasis kearifan lokal. Hasil pengujian oleh validator dan tes hasil belajar peserta didik dijadikan rujukan untuk menentukan kelayakan dan keefektifan metode pembelajaran dukasimera yang dikembangkan.

Data dikumpulkan dengan teknik observasi, wawancara, angket, dan tes. Observasi digunakan untuk mendapatkan data tentang aktivitas peserta didik dalam diskusi, hasil penilaian produk, presentasi, poster, dan pameran. Teknik wawancara dan angket digunakan untuk mendapatkan informasi tentang kevalidan RPP dan LKDP. Sedangkan teknik tes digunakan untuk mendapatkan data hasil belajar peserta didik pada pembelajaran langsung (kelompok kontrol) dan pembelajaran dengan metode dukasimera berbasis kearifan lokal (kelompok eksperimen).

Data dalam penelitian ini dianalisis dengan menggunakan analisis despkriptif untuk menentukan kelayakan dan keefektifan metode pembelajaran dukasimera berbasis kearifan lokal. Kelayakan metode pembelajaran ditentukan berdasarkan hasil validasi oleh ahli terhadap RPP dan LKPD yang dikembangkan. Sedangkan keefektifan metode pembelajaran ditentukan berdasarkan data empirik yang diperoleh dari tes hasil belajar peserta didik. Data hasil belajar peserta didik yang dibandingkan, meliputi rerata hasil belajar, nilai tertinggi dan terendah, ketuntasan belajar, dan standar deviasi. Signifikansi perbedaan hasil belajar peserta didik diuji dengan uji-t pada taraf signifikansi $5 \%$. Metode dukasimera dinyatakan efektif, jika hasil belajar peserta didik kelompok eksperimen lebih tinggi dan berbeda secara signifikan dari peserta didik kelompok kontrol.

\section{HASIL PENELITIAN DAN PEMBAHASAN}

\section{Hasil Penelitian}

Penelitian ini bertujuan mengembangkan metode pembelajaran dukasimera berbasis kearifan lokal yang diimplementasikan pada pembelajaran prakarya dan kewirausahaan. Dukasimera merupakan akronim dari produk, presentasi, dan pameran dan berorientasi kearifan lokal yang ada di sekitar SMAN 1 Banjar, Buleleng, Bali.

Analisis kebutuhan dilakukan untuk mengidentifikasi masalah dan melakukan analisis tindak lanjut yang diperlukan sebagai bentuk solusi. Hasil analisis kebutuhan dan tindak lanjut menemukan, bahwa (1) kompetensi sikap, pengetahuan, keterampilan, dan pemahaman konsep peserta didik perlu ditumbuhkembangkan melalui pengintegrasian kearifan lokal dalam pembelajaran; (2) perlu menerapkan metode yang kreatif dan inovatif sehingga dapat meningkatkan keterlibatan peserta didik dalam pembelajaran; dan (3) materi pembelajaran agar aktual, faktual, dan kontekstual sehingga pembelajaran lebih bermakna. 
Berdasarkan hasil analisis kebutuhan ditemukan bahwa perlu upaya perbaikan kualitas metode pembelajaran pada mata pelajaran prakarya dan kewirausahaan. Salah satu upaya dimaksud adalah mengembangkan metode pembelajaran dukasimera berbasis kearifan lokal.

Desain awal produk pada penelitian ini adalah rencana pelaksanaan pembelajaran (RPP) dan lembar kerja peserta didik (LKPD) yang mengakomodasi kegiatan pembuatan produk, presentasi, dan pameran berbasis kearifan lokal. RPP yang dikembangkan mengacu pada Permendikbud Nomor 22 Tahun 2016. LKPD yang dikembangkan berisi tujuan pembelajaran, rangkuman materi, dan bahan diskusi.

Validasi desain produk pengembangan metode pembelajaran dukasimera berbasis kearifan lokal dilakukan untuk mengetahui kelayakan konstruk dan konten RPP dan LKPD. Validasi RPP meliputi 20 indikator sedangkan validasi LKPD meliputi 11 indikator penilaian.

Dua puluh indikator validasi RPP, yakni 1) kesesuaian dengan KI dan KD, 2) kecukupan dan kejelasan identitas, 3) rumusan tujuan pembelajaran, 4) kesesuaian rumusan tujuan pembelajaran dengan indikator pencapaian kompetensi, 5) ketepatan rumusan tujuan pembelajaran terkait dengan KD pengetahuan dan keterampilan, 6) kedalaman/keluasan materi pelajaran, 7) ketepatan/kebenaran materi pelajaran, 8) kesesuaian langkah-langkah pembelajaran, 9) keruntutan langkah-langkah pembelajaran, 10) kecukupan alokasi waktu, 11) kecukupan sumber bahan belajar/referensi, 12) ketepatan pemilihan macam media dan/atau sumber belajar/pembelajaran, 13) kesesuaian media pembelajaran, 14) ketepatan pemilihan teknik penilaian, 15) ketepatan pemilihan bentuk/macam instrumen penilaian, 16) ketepatan pemilihan teknologi, informasi, dan komunikasi (TIK), 17) kesesuaian antara isi TIK dengan strategi/pendekatan/model pembelajaran, 18) pencapaian ketiga domain kemampuan peserta didik, 19) langkah-langkah pembelajaran memuat pengembangan kemampuan berpikir tingkat tinggi (HOTS), dan 20) rumusan langkah-langkah pembelajaran memuat pengembangan karakter peserta didik.

Sebelas indikator validasi LKPD, meliputi 1) sistematis, 2) materi/ tugas yang esensial, 3) masalah sesuai dengan tingkat kognisi peserta didik, 4) setiap kegiatan mempunyai tujuan jelas, 5) dapat menumbuhkan rasa ingin tahu peserta didik, 6) dilengkapi dengan gambar dan ilustrasi, 7) bahasa sesuai dengan EYD, 8) bahasa sesuai dengan tingkat perkembangan kognisi peserta didik, 9) bahasa yang digunakan komunikatif, 10) kalimat yang digunakan jelas dan mudah dimengerti, dan 11) kejelasan petunjuk atau arahan.

Validasi RPP dan LKPD yang dikembangkan dilakukan oleh tiga validator. Ketiga validator tersebut, yakni pengawas pada Dinas Pendidikan Provinsi Bali yang telah menjadi guru sejak tahun 1984 dan menjadi pengawas sejak tahun 2009, guru mata pelajaran prakarya dan kewirausahaan pada SMAN 1 Banjar yang telah menjadi guru sejak tahun 2004, dan guru prakarya dan kewirausahaan pada SMAN 1 Banjar yang telah menjadi guru sejak tahun 2012. Hasil validasi ketiga validator terhadap RPP dan LKDP disajikan pada tabel sebagai berikut. 
Tabel 1. Hasil Validasi dan Kriteria Kualitas RPP dan LKPD

\begin{tabular}{cccccc}
\hline \multirow{2}{*}{$\begin{array}{c}\text { o } \\
\text { Validator }\end{array}$} & & \multicolumn{2}{c}{ RPP } & \multicolumn{2}{c}{ LKDP } \\
\cline { 3 - 6 } 1 & $(1)$ & Skor & Kualifikasi & Skor & Kualifikasi \\
\hline 2 & $(2)$ & 72,00 & Sangat Baik & 40,00 & Sangat Baik \\
\hline 3 & $(3)$ & 77,00 & Sangat Baik & 43,00 & Sangat Baik \\
\hline & Rerata & $\mathbf{7 5 , 0 0}$ & Sangat Baik & $\mathbf{4 1 , 6 7}$ & Sangat Baik \\
\hline
\end{tabular}

Hasil validasi menunjukkan rerata skor RPP sebesar 75,00 dan LKDP sebesar 41,67 dengan kualifikasi sangat baik. Dengan demikian, RPP dan LKDP layak atau valid diterapkan dalam pembelajaran.

Implementasi pengembangan metode pembelajaran dukasimera berbasis kearifan lokal dilaksanakan secara terbatas di SMAN 1 Banjar, Buleleng, Bali. Implementasi dilakukan untuk mengetahui keefektifan metode yang dikembangkan. Adapun langkah-langkah penerapan metode pembelajaran dukasimera berbasis kearifan lokal, yakni (1) kegiatan berbasis produk, meliputi eksplorasi ide/gagasan berbasisi kearifan lokal, membuat rancangan/sketsa produk, dan penyempurnaan dan finalisasi rancangan produk; (2) kegiatan berbasis presentasi, meliputi membuat media presentasi dalam bentuk poster dan powerpoint/video dan mempresentasikan proses pembuatan produk; dan (3) kegiatan berbasis pameran, meliputi menata produk dan poster dalam pameran dan mengomunikasikan ide/gagasan dan produk kepada pengunjung pameran.

Melalui pembelajaran dengan metode dukasimera berbasis kearifan lokal terjadi peningkatan keterlibatan peserta didik secara signifikan dalam pembelajaran. Untuk mengetahui keefektifan metode pembelajaran dukasimera berbasis kearifan lokal maka dibandingkan dengan pembelajaran langsung. Dalam hal ini pembelajaran dengan metode dukasimera berbasis kearifan lokal sebagai kelompok eksperimen dan pembelajaran langsung sebagai kelompok kontrol.

Hasil observasi menunjukkan bahwa aktivitas peserta didik, meliputi diskusi, tanya jawab, saling berbagi, mengajukan ide, dan mengomunikasikan ide lebih banyak muncul pada kelompok eksperimen dibanding dengan kelompok kontrol. Artinya, kualitas proses pembelajaran dengan metode dukasimera lebih baik dibandingkan dengan pembelajaran langsung. Melalui wawancara mendalam, ditemukan bahwa peserta didik merasa lebih senang belajar, kreativitas dan inovasi lebih berkembang, dan menjadi lebih berani berbicara di depan publik.

Hasil belajar peserta didik setelah pelaksanaan pembelajaran dengan metode dukasimera (kelompok eksperimen) dan pembelajaran langsung (kelompok kontrol) ditentukan berdasarkan hasil tes pemahaman konsep prakarya dan kewirausahaan pada aspek kajian kerajinan. Perbedaan hasil tes pemahaman konsep kelompok eksperimen dan kontrol, disajikan pada tabel berikut. 
Tabel 2. Perbedaan Hasil Belajar Peserta Didik pada Pembelajaran dengan Metode Dukasimera Berbasis Kearifan Lokal (Eksperimen) dan Pembelajaran Langsung (Kontrol)

\begin{tabular}{llccc}
\hline No & \multicolumn{1}{c}{ Statistik } & Eksperimen & Kontrol & Selisih \\
\hline 1 & Jumlah Peserta Didik & 33 & 35 & 2 \\
\hline 2 & Rerata Nilai & 77,08 & 68,49 & 8,59 \\
\hline 3 & Nilai Tertinggi & 97 & 95 & 2 \\
\hline 4 & Nilai Terendah & 54 & 43 & 11 \\
\hline 5 & Ketuntasan Belajar & $80,0 \%$ & $51,4 \%$ & $28,6 \%$ \\
\hline 6 & Standar Deviasi & 11,32 & 11,49 & 0,17 \\
\hline
\end{tabular}

Berdasarkan Tabel 2, terlihat bahwa di semua parameter kualitas hasil belajar, peserta didik yang mengikuti pembelajaran dengan metode dukasimera berbasis kearifan lokal (eksperimen) lebih baik dari pembelajaran langsung (kontrol). Standar deviasi antara dua kelompok relatif sama, artinya variasi nilai antar kedua kelompok juga relatif sama.

Sebelum menentukan signifikansi perbedaan antara kelompok eksperimen dengan kelompok kontrol, terlebih dahulu dilakukan uji normalitas. Dalam hal ini pengujian normalitas dengan Chi Kuadrat $\left(\chi^{2}\right)$.

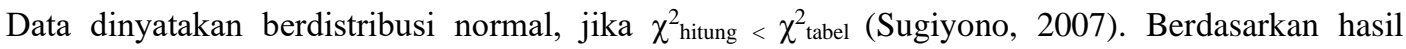
perhitungan, ditemukan harga $\chi^{2}$ hitung sebesar 9,323. Harga $\chi^{2}$ tabel dengan derajat kebebasan 5 dan taraf signifikansi 5\% adalah sebesar 11,070. Oleh karena $\chi^{2}$ hitung $<\chi^{2}$ tabel maka data hasil belajar peserta didik kelas X-MIPA-2 (kelompok eksperimen) berdistribusi normal. Hal yang sama dilakukan untuk pengujian normalitas data hasil belajar peserta didik kelas X-MIPA-3 (kelompok kontrol) yang mengikuti pembelajaran langsung. Berdasarkan hasil perhitungan, ditemukan harga $\chi^{2}$ hitung sebesar 3,467 . Harga $\chi^{2}$ tabel dengan derajat kebebasan 5 dan taraf signifikansi 5\% adalah sebesar 11,070. Oleh karena $\chi^{2}$ hitung $<\chi_{\text {tabel }}^{2}$ maka disimpulkan bahwa data hasil belajar peserta didik kelas X-MIPA-3 (kelompok kontrol) berdistribusi normal.

Pengujian signifikansi perbedaan hasil belajar peserta didik pada pembelajaran dengan metode dukasimera berbasis kearifan lokal dan pembelajaran langsung dilakukan dengan uji-t. Langkahlangkah pengujiannya, yakni menentukan rerata skor, varian, jumlah subjek kedua kelompok,

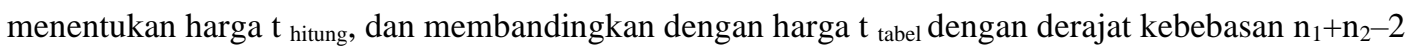
pada taraf signifikansi 5\% (Sudjana, 2002). Data hasil belajar peserta didik berbeda secara signifikan, jika harga $\mathrm{t}_{\text {hitung }}>\mathrm{t}_{\text {tabel }}$. Berdasarkan hasil perhitungan uji-t, diperoleh data seperti disajikan pada tabel berikut.

Tabel 3. Rangkuman Uji-t untuk Hasil Belajar Peserta Didik Kelompok Eksperimen (X-MIPA-2) dan Kelompok Kontrol (X-MIPA-3)

\begin{tabular}{|c|c|c|c|c|c|}
\hline No & Statistik & $\begin{array}{c}\text { Kelompok } \\
\text { Eksperimen }\end{array}$ & $\begin{array}{c}\text { Kelompok } \\
\text { Kontrol }\end{array}$ & $\mathbf{t}$ hitung & $\begin{array}{c}\mathbf{t}_{\text {tabel }(\mathrm{db}=\mathbf{6 6} ;} \\
\mathbf{5 \% )}\end{array}$ \\
\hline 1 & Jumlah Data (n) & 33 & 35 & \multirow{3}{*}{3,106} & \multirow{3}{*}{1,980} \\
\hline 2 & Rerata Skor (M) & 77,08 & 68,49 & & \\
\hline 3 & Varian $\left(S^{2}\right)$ & 128,1 & 131,91 & & \\
\hline
\end{tabular}


Berdasarkan tabel, harga $t_{\text {hitung }}$ sebesar 3,106 dan harga $t_{\text {tabel }}$ dengan derajat kebebasan adalah 66 pada taraf signifikansi $5 \%$ sebesar 1,980. Oleh karena $t_{\text {hitung }}>t_{\text {tabel }}(3,106>1,980)$, maka rerata hasil belajar peserta didik pada kelompok eksperimen berbeda secara signifikan dengan kelompok kontrol. Dalam hal ini hasil belajar peserta didik kelompok eksperimen yang mengikuti pembelajaran dengan metode dukasimera berbasis kearifan lokal lebih baik dari kelompok kontrol yang mengikuti pembelajaran langsung.

\section{Pembahasan}

Dukasimera merupakan akronim dari produk, presentasi, dan pameran. Pada pembelajaran berbasis produk, peserta didik terlibat dalam proses penggalian ide atau gagasan untuk membuat produk kerajinan berbasis kearifan lokal. Dalam hal ini, kreativitas dan inovasi peserta didik digali, dimunculkan, dan dikembangkan. Peserta didik saling berbagi, berdiskusi, menunjukkan kelebihan dan kekurangan, dan saling menghargai pendapat orang lain. Oleh karena itu, pembelajaran dengan metode dukasimera melalui pembuatan produk berbasis kearifan lokal dapat mengembangkan keterampilan berpikir kritis, kreatif, inovatif, menghargai perbedaan pendapat, dan berkomunikasi efektif. Hal ini sesuai dengan pendapat Dewy et al., (2016) bahwa pembelajaran berbasis produk dapat mengembangkan kemampuan berpikir, keterampilan, dan bekerjasama.

Berbagai produk kerajinan berbasis kearifan lokal mampu dirancang dan dibuat peserta didik. Produkproduk tersebut, diantaranya 1) miniatur tempat suci, 2) bale kulkul, 3) meru, 4) padmasana, 5) janur, 6) wayang, dan 7) topeng. Setiap produk disertai dengan deskripsi tentang arti, sejarah, dan manfaat dari setiap produk yang dibuat. Melalui kegiatan pembelajaran berbasis produk maka peserta didik belajar sambal bekerja sehingga sikap, pengetahuan dan keterampilan secara bersamaan terasah lebih baik.

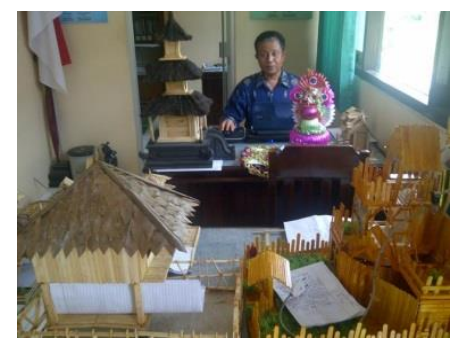

Gambar 1.

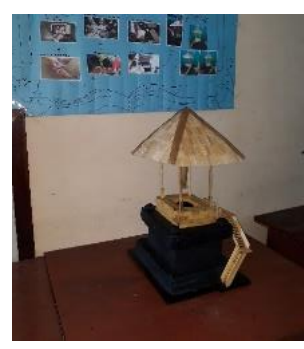

Gambar 2.

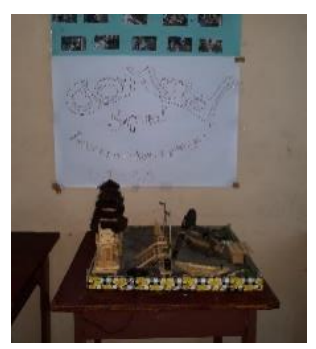

Gambar 3.

Beberapa produk kerajinan berbasis kearifan lokal

Bale kulkul, salah satu produk berbasis kearifan lokal
Miniatur Pura Tambilngan, produk berbasis kearifan lokal

Melalui kegiatan presentasi, peserta didik dilatih mengemukakan pendapat, menjawab pertanyaan, berani tampil di depan umum, sikap percaya diri, dan bertanggung jawab. Peserta didik diarahkan terlibat mempersiapkan media presentasi berupa video dan/atau poster. Dalam konteks ini, muncul rasa kebersamaan dan saling berbagi dalam kelompok. Kondisi ini akan melahirkan keterampilan berkomunikasi, rasa percaya diri tinggi, dan berpikir kritis. Hal ini sesuai dengan penjelasan Bowman (dalam Millah, 2015), bahwa metode presentasi mampu mengoptimalkan keterlibatan peserta didik dalam pembelajaran, menumbuhkembangkan berpikir kritis dan analitis. Metode presentasi 
berpotensi menghidupkan suasana kelas, meningkatkan rasa percaya diri, dan memperkuat kemampuan literasi peserta didik.

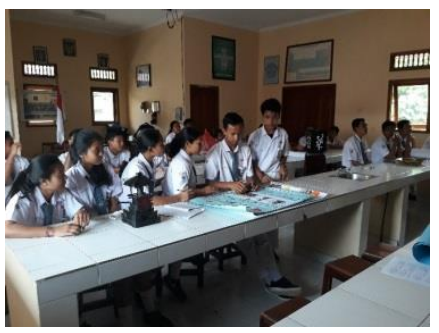

Gambar 4.

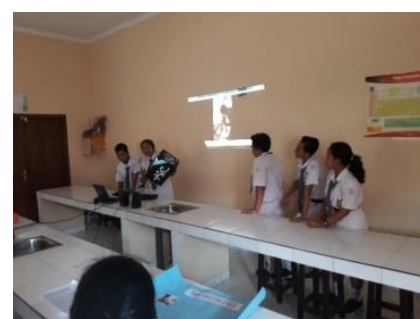

Gambar 5.

Persiapan presentasi produk kerajinan berbasis kearifan lokal

Presentasi produk menggunakan video dan poster

Dalam kegiatan pameran, peserta didik melakukan penataan pameran, mempersiapkan produk, dan mengawal pameran. Hal ini akan menumbuhkan rasa tanggung jawab, gotong royong, dan rasa kebersamaan. (Suranto, 2005) menyebutkan bahwa kegiatan pameran produk hasil pembelajaran dapat meningkatkan rasa bangga, menumbuhkan rasa percaya diri, memotivasi lahirnya kreativitas dan inovasi yang berkelanjutan.

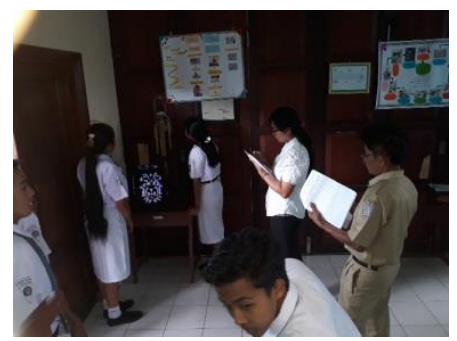

Gambar 6.

Pameran produk kerajinan berbasis kearifan lokal

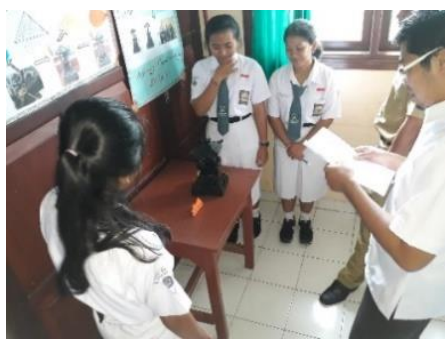

Gambar 7.

Peserta didik menjelaskan produk yang dipamerkan

Pembelajaran dengan metode dukasimera berbasis kearifan lokal dapat menumbuhkembangkan potensi dan kompetensi peserta didik pada aspek sikap, keterampilan, dan pengetahuan pada mata pelajaran prakarya dan kewirausahaan. Di pihak lain dapat memunculkan jiwa kewirausahaan di kalangan peserta didik. Menurut Carree dan Thurik (2010), kewirausahaan merupakan manifestasi kemampuan dan kemauan individual, baik sendiri, dalam tim, di dalam ataupun di luar organisasi untuk menciptakan peluang baru, dan mengenalkan ide mereka ke pasar, dalam upaya menghadapi ketidakpastian dan keterbatasan, melalui pengambilan keputusan lokasi, bentuk dan penggunaan sumber daya dan lembaga. Oleh karena itu, kewirausahaan adalah karakteristik perilaku. Dalam konteks pembelajaran di sekolah, maka kewirausahaan, bukan hanya berkaitan dengan usaha, tetapi keberanian menggali ide, menemukan masalah, dan mencari solusi yang kreatif dan inovatif.

Pengintegrasian kearifan lokal, diyakini mampu memperkuat karakter mulia peserta didik. Kearifan lokal sering disamakan artinya dengan kebijakan setempat (local wisdom), pengetahuan setempat (local knowledge), dan kecerdasan setempat (local genius) (Naing dkk., 2009; Salam dkk., 2019). Melalui kajian kearifan lokal, peserta didik menemukenali nilai-nilai luhur yang terkandung dalam 
setiap kearifan lokal. Selanjutnya, dijadikan sebagai rujukan untuk berperilaku dalam kehidupan bermasyarakat. Oleh karena itu, dengan mengkaji kearifan lokal akan terjadi peningkatan pada karakter religius, nasionalis, gotong royong, mandiri, dan integritas. Brata (2016) menjelaskan bahwa kearifan lokal merupakan elemen budaya yang harus digali, dikaji, dan direvitalisasi, karena esensi kearifan lokal sangat penting dalam penguatan fondasi jati diri bangsa dalam menghadapi tantangan globalisasi. Dengan demikian menggali, menemukenali, dan menumbuhkembangkan pemahaman terhadap kearifan lokal berpotensi memperkuat karakter baik pada peserta didik.

Hasil penelitian menunjukkan bahwa keterlibatan peserta didik dalam pembelajaran dengan metode dukasimera lebih tinggi dibandingkan dengan pembelajaran langsung. Aktivitas peserta didik dalam berdiskusi, tanya jawab, saling berbagi, mengajukan ide, dan mengomunikasikan ide lebih banyak muncul pada pembelajaran dengan metode dukasimera berbasis kearifan lokal. Pembelajaran dengan metode yang dikembangkan melibatkan peserta didik mulai dari penggalian ide, perancangan produk, produksi produk, dan evaluasi produk. Artinya, peserta didik diberikan ruang dan waktu belajar yang lebih banyak. Kondisi ini akan meningkatkan kualitas proses dan hasil belajar peserta didik. Hal ini sesuai dengan pendapat Capel dan Whitehead (2015) bahwa perencanaan pembelajaran yang baik hendaknya melibatkan kegiatan pengalokasian waktu, pemilihan metode pembelajaran yang tepat, menciptakan minat peserta didik, dan membangun lingkungan belajar produktif. Oleh karena itu, kualitas proses pembelajaran dengan metode dukasimera berbasis kearifan lokal lebih baik dibandingkan dengan pembelajaran langsung.

Hasil tes pemahaman konsep peserta didik pada pembelajaran dengan metode dukasimera (kelompok eksperimen) juga menunjukkan rerata yang lebih tinggi dari peserta didik dengan pembelajaran langsung (kelompok kontrol). Hal ini karena peserta didik pada pembelajaran dengan metode dukasimera lebih terlibat aktif. Di pihak lain terdapat ruang dan waktu yang lebih luas bagi peserta didik untuk mengekplorasi materi pembelajaran. Kegiatan belajar tidak hanya terjadi di lingkungan sekolah, tetapi juga terjadi di lingkungan keluarga dan masyarakat dengan permasalahan yang lebih kompleks. Kondisi inilah yang memicu dan memacu kemampuan pemecahan masalah sehingga mengembangkan keterampilan berpikir kritisnya. Kusumawati (2014) menyebutkan bahwa keterampilan berpikir kritis memungkinkan peserta didik memeriksa isu, melihat fenomena dari sudut pandang yang berbeda, dan memiliki fleksibilitas untuk merestrukturisasi pemikiran. Oleh karena itu, agar mampu berpikir secara kritis, seseorang harus membaca dengan kritis. Peningkatan kemampuan berpikir kritis bermuara pada peningkatan pemahaman konsep peserta didik terhadap materi yang dikaji, sehingga meningkatkan hasil belajarnya.

Pembelajaran dengan metode dukasimera terbukti mampu meningkatkan hasil belajar peserta didik pada kompetensi sikap, keterampilan, dan pengetahuan. Pembelajaran dengan metode dukasimera mampu menumbuhkembangkan semua potensi dan kompetensi peserta didik. Melalui metode dukasimera, peserta didik dilibatkan dalam pembuatan produk. Sehingga belajar sambil bekerja (learning by doing). Kondisi ini mampu mengarahkan peserta didik untuk berpikir kreatif, inovatif, bekerja sama, dan saling berbagi. Selanjutnya, melalui presentasi dan pameran, peserta didik dilibatkan dalam komunikasi aktif, memberikan argumentasi dan menjelaskan setiap tahap pada proses pembuatan produk. Muara dari hal ini adalah keterampilan berpikir kritis, kreatif, kolaboratif, kooperatif, dan komunikatif bagi peserta didik dapat ditumbuhkembangkan. Di pihak lain, pembelajaran dengan metode dukasimera dapat meningkatkan karakter religius, nasionalis, gotong 
royong, mandiri, dan integritas di kalangan peserta didik. Artinya, ada penguatan pendidikan karakter yang dihasilkan melalui pembelajaran dengan metode dukasimera berbasis kearifan lokal.

\section{KESIMPULAN DAN SARAN}

\section{Kesimpulan}

Berdasarkan hasil penelitian dan pembahasan, dapat disimpulkan bahwa metode pembelajaran dukasimera berbasis kearifan lokal dapat dikembangkan pada mata pelajaran prakarya dan kewirausahaan untuk mengoptimalkan keterlibatan peserta didik dalam pembelajaran sehingga dapat menumbuhkembangkan potensi dan kompetensinya untuk meningkatkan kualitas proses dan hasil belajar. Rerata hasil belajar peserta didik yang mengikuti pembelajaran dengan metode dukasimera berbasis kearifan lokal adalah 77,08 lebih tinggi dari yang mengikuti pembelajaran langsung, yakni 68,49 dan berbeda secara signifikan sesuai harga $t_{\text {hitung }}>t_{\text {tabel }}(3,106>1,980)$. Hasil belajar peserta didik aspek pengetahuan pada pembelajaran dengan metode dukasimera berbasis kearifan lokal lebih baik dibandingkan dengan pembelajaran langsung.

\section{Saran}

Metode pembelajaran dukasimera berbasis kearifan lokal sangat potensial meningkatkan keterlibatan peserta didik dalam menumbuhkembangkan kemampuan abad 21 dan penguatan pendidikan karakter. Oleh karena itu, disarankan dapat diterapkan di sekolah-sekolah untuk meningkatkan kualitas proses dan hasil belajar peserta didik. Potensi peserta didik perlu ditumbuhkembangkan secara berkelanjutan melalui pelaksanaan pembelajaran dengan metode bervariasi, sehingga disarankan agar guru dan stakeholders pendidikan lainnya dapat mengembangkan pendekatan, model, atau metode pembelajaran yang kreatif dan inovatif agar potensi dan kompetensi peserta didik dapat ditingkatkan secara optimal.

\section{DAFTAR RUJUKAN}

Almomen, R. K., Kaufman, D., Alotaibi, H., Al-Rowais, N. A., Albeik, M., \& Albattal, S. M. (2016). Applying the ADDIE - analysis, design, development, implementation \& evaluationinstructional design model to continuing professional development for primary care physicians in Saudi Arabia. International Journal of Clinical Medicine, 7(8), 538-546.

Astra, I., \& Semadi, G. (2004). Revitalisasi Kearifan Lokal Dalam Upaya Memperkokoh Jati Diri Bangsa. I Wayan Ardika \& I Nyoman Darmaputra. Denpasar: FS Unud \& Bali Mangsi Press.

Branch, R. M. (2009). Instructional design: The ADDIE approach (Vol. 722). Springer Science \& Business Media.

Brata, I. B. (2016). Kearifan budaya lokal perekat identitas bangsa. Jurnal Bakti Saraswati (JBS), $5(1)$.

Capel, S., \& Whitehead, M. (2015). Learning to Teach Physical Education in the Secondary School: A companion to school experience. Routledge. 
Carree, M. A., \& Thurik, A. R. (2010). The impact of entrepreneurship on economic growth. In Handbook of entrepreneurship research (pp. 557-594). Springer.

Creswell, J. W., \& Poth, C. N. (2018). Qualitative inquiry Research Design Choosing Among Five Approaches (Vol. 53, Issue 9). SAGE Publications Ltd. https://doi.org/10.1017/CBO9781107415324.004

Davis, A. L. (2013). Using instructional design principles to develop effective information literacy instruction: The ADDIE model. College \& Research Libraries News, 74(4), 205-207.

Dewy, M. S., Ganefri, G. S., \& Kusumaningrum, I. (2016). Pengembangan Model Pembelajaran Berbasis Produk Pada Mata Kuliah Praktek Elektronika Daya. VOLT: Jurnal Ilmiah Pendidikan Teknik Elektro, 1(1), 15-28.

Iswan, \& Herwina. (2018). Pengutan Pendidikan Karakter Persektif Islam Era Millenial IR. 4.0. Prosiding Seminar Nasional Pendidilam Era Revolusi.

Kementerian Pendidikan dan Kebudayaan Republik Indonesia. (2017). Prakarya \& Kewirausahaan. Yrama Widia.

Kusumawati, S. N. (2014). Pengaruh Pembelajaran Berbasis Otak melalui Learning Cycle terhadap Kemampuan Berpikir Kritis, Berpikir Kreatif, \& Hasil Belajar Biologi Siswa SMK Kota Malang. Program Pascasarjana UM.

Lohr, L. (1998). Using ADDIE to design a web-based training interface. Society for Information Technology \& Teacher Education International Conference, 452-455.

Millah, D. (2015). Audience centered pada Metode presentasi sebagai aktualisasi pendekatan Student centered Learning. Edukasia: Jurnal Penelitian Pendidikan Islam, 10(2).

Muhammad, M., \& Nurdyansyah, N. (2015). Pendekatan Pembelajaran Saintifik. Nizamia Learning Center.

Mulyaningsih, I., Suwandi, S., Setiawan, B., \& Rohmadi, M. (2016). Model Pembelajaran Menulis Ilmiah berbasis PARMI (Produksi, Atensi, Retensi, Motivasi, \& Inovasi) \& Penerapannya.

Naing, N., Santosa, H. R., \& Soemarno, I. (2009). Kearifan Lokal Tradisional Masyarakat Nelayan pada Permukiman Mengapung di Danau Tempe Sulawesi Selatan. Local Wisdom, 1(1), 19-26.

Saggaf, H. M. S. (2016). Kebijakan Pendidikan Di Era Otonomi Daerah Dalam Memperkuat Karakter Bangsa. Jurnal Ilmiah Ilmu Administrasi Publik, 5(2), 106-112.

Salam, R., Salam, H. A., \& Hafidz, A. N. (2019). Pelayanan Publik berbasis Kearifan Lokal. Jurnal Administrasi Publik, 8(2), 21-28.

Sarbani, Y. A., Astuti, E. S., \& Kertahadi, K. (2013). Analisis Penggunaan Teknologi Informasi pada Tenaga Kependidikan Sekolah (Studi Pada Tenaga Kependidikan Di Sekolah Milik Perkumpulan Dharmaputri Melalui Model UTAUT). PROFIT: JURNAL ADMINISTRASI BISNIS, 7(1).

Shibley, I., Amaral, K. E., Shank, J. D., \& Shibley, L. R. (2011). Designing a blended course: Using ADDIE to guide instructional design. Journal of College Science Teaching, 40(6), 80. 
Sukmawati, S. (2017). Implementasi Pendidikan Karakter di Sekolah Menengah Pertama Negeri Kabupaten Maros. Jurnal Ad'ministrare, 4(2), 76-82.

Suranto AW. (2005). Komunikasi Perkantoran. Media Wacana.

Widodo, A. (2007). Konstruktivisme dan Permbelajaran Sains. 